2012

\title{
Ghosts of law and humanities (past, present, future)
}

Marett Leiboff

University of Wollongong, marett@uow.edu.au

Publication Details

M. Leiboff, 'Ghosts of law and humanities (past, present, future)' (2012) 36, The Australian Feminist Law Journal 3-17.

Research Online is the open access institutional repository for the University of Wollongong. For further information contact the UOW Library: research-pubs@uow.edu.au 


\title{
Ghosts of law and humanities (past, present, future)
}

\begin{abstract}
This introductory essay teases out the ghosts of a Law and Humanities Past to find an unlikely candidate as an advocate for a relationship between law and the humanities: Sir William Blackstone. In contemplating what constitutes Law and Humanities Futures, it is apparent that law has forgotten about this past, and has created an imagined present for law, absent the humanities. In introducing the special issue on Law and Humanities Futures, the essay weaves the story of Otto Kahn- Freund and the concept of Bildung or 'formation' with Kahn-Freund's advocacy-using Blackstone-for its importance in the training of lawyers. In drawing upon Goethe, Yes Minister, and the Oxford of the 1950s and 1960s and Nazi Germany, this account humanises the humanities through Kahn-Freund, a refugee German Jewish labour lawyer, in order to make the claim that the humanities are fundamentally aligned with the civil and civilising. However, to dissociate the human from humanities can lead to the uncivil and inhumane. Drawing upon history and various modes of culture, the essay asserts that Bildung lights a path for law through the intersections and interdisciplines that constitute and shape the humanities in their broadest conception, of the human, of the civil, and the civilising-those concepts and ideas that we can see in and of the past and present-and to reveal what might be missing from law and humanities futures.
\end{abstract}

\section{Keywords}

ghosts, law, present, humanities, future, past

\section{Disciplines}

Law

\section{Publication Details}

M. Leiboff, 'Ghosts of law and humanities (past, present, future)' (2012) 36, The Australian Feminist Law Journal 3-17. 


\title{
GHOSTS OF LAW AND HuMANities (PAST, Present, Future)
}

\begin{abstract}
Marett Leiboff
Abstract .This introductory essay teases out the ghosts of a Law and Humanities Past to find an unlikely candidate as an advocate for a relationship between law and the humanities: Sir William Blackstone. In contemplating what constitutes Law and Humanities Futures, it is apparent that law has forgotten about this past, and has created an imagined present for law, absent the humanities. In introducing the special issue on Law and Humanities Futures, the essay weaves the story of Otto KahnFreund and the concept of Bildung or 'formation' with Kahn-Freund's advocacy-using Blackstone-for its importance in the training of lawyers. In drawing upon Goethe, Yes Minister, and the Oxford of the 1950s and 1960s and Nazi Germany, this account humanises the humanities through Kahn-Freund, a refugee German Jewish labour lawyer, in order to make the claim that the humanities are fundamentally aligned with the civil and civilising. However, to dissociate the human from humanities can lead to the uncivil and inhumane. Drawing upon history and various modes of culture, the essay asserts that Bildung lights a path for law through the intersections and interdisciplines that constitute and shape the humanities in their broadest conception, of the human, of the civil, and the civilising - those concepts and ideas that we can see in and of the past and present - and to reveal what might be missing from law and humanities futures.
\end{abstract}

\subsection{A Tale of Two Lectures}

The early humanists were lawyers, they wrote the book, and they read the law. The contemporary humanist is a nonlawyer. ${ }^{1}$

On 11 May 1965, Otto Kahn-Freund, ${ }^{2}$ the German Jewish refugee labour lawyer and Professor of Comparative Law at the University of Oxford, ${ }^{3}$ gave a Special University Lecture at the London

* Marett Leiboff is an Associate Professor in the Faculty of Law at the University of Wollongong. She is a member of the Law and Popular Cultures Group of the Legal Intersections Research Centre and Vice President of the Law Literature and Humanities Association of Australasia. She would like to acknowledge and thank Judy Grbich and the Editorial Board for inviting her to edit this special issue on this topic and for Judy's patience and forbearance during the latter stages of its completion. Email marett@uow.edu.au.

1 Goodrich Peter 'The Theatre of Emblems: On the Optical Apparatus and the Investiture of Persons' (2012) 8 Law, Culture and the Humanities 47 at 49.

2 Kahn-Freund was born in Frankfurt-am-Main in 1900 and died in England in 1979: Baron Wedderburn of Charlton 'Professor Sir Otto Kahn-Freund' (1979) 42 Modern Law Review 609.

3 Dukes Ruth 'Otto Kahn-Freund and Collective Laissez-Faire: An Edifice without a Keystone?' (2009) 72 Modern Law Review 220 at 224 cited Kahn-Freund's unfinished autobiography that commenced: 'The most important single fact of my life is that I am a Jew.' Cited in Ramm T 'Otto Kahn-Freund und Deutschland' in F Gamillscheg (ed) In Memoriam Sir Otto Kahn-Freund Munich Beck 1980 p xxi. 
School of Economics and Political Science (the LSE). At the age of 65, his topic, 'Reflections on Legal Education', was delivered smack in the middle of the Swinging Sixties, only four years after the publication of HLA Hart's path-breaking positivist tract, The Concept of Law, and shortly after he-Kahn-Freund-had moved to Oxford, where Hart was Professor of Jurisprudence, a post he had held from 1952.

Let me push the pause button, for I am sure you are thinking that this is a very odd way to begin a special issue of the Australian Feminist Law Journal on Law and Humanities Futures by turning back nearly 50 years to a country-England-whose legal significance for Australia has faded like so many sun-drenched home movies, leaving behind spectral, sepiaed remnants of once solid images and representations. The very brief opening paragraph is a mere fragment, but its words will have already left an impression, a series of pictures may have come to mind: times and places remembered, times and places imagined, or blankness, nothing. What has come to mind, of course, depends on your autobiography. So please be patient and bear with me as this essay introduces by way of intro-duction, ${ }^{5}$ for it won't pretend to introduce by synopsis. Instead, a tad of this, and a bit of that, like fractured remnants drawn upon to construct memory and meaning. Now, are you sitting comfortably?

You may never have heard of Otto Kahn-Freund, but we may take it as a given that his life and career was remarkable. Born in Frankfurt-am-Main in 1900, he was educated in history and law at the Universities of Heidelberg, Leipzig and Frankfurt-am-Main. ${ }^{6}$ With a doctorate on labour law, he was appointed a labour court judge in 1929 in Weimar Germany. Dismissed by the Nazis in 1933 for deciding a case against them, he had to escape soon after. ${ }^{7}$ Settling in England, he spent nearly half his life associated with the Law Department of the LSE, firstly as a refugee student and then as a lecturer. When he arrived in 1933, though a published scholar and bearer of high academic qualifications, he commenced an LL M (or MA) and was then appointed to a position of assistant lecturer in $1935 .^{8}$

Despite or perhaps because of this background, Kahn-Freund knew his audience, their foibles and conceits, their sensibilities and prejudices. Drawing on the principle of 'slowly slowly catchee monkey' (for he would need to take very cautious steps in making his case, so as not to alienate) he lured his audience in with the cleverest and subtlest of rhetorical strategies. Calculating that they may be suspicious of the intrusion of the foreign concept that he was about to deploy-Bildung - he called in aid one of their own, the venerated Blackstone. Blackstone's Inaugural Lecture as Vinerian Professor of Common Law at the University of Oxford, KahnFreund observed, argued for the teaching of the common law in a university setting because knowledge of some law was "part of the necessary culture, the "formation" or "Bildung" of a

\footnotetext{
Kahn-Freund Otto 'Reflections on Legal Education’ (1966) 29 Modern Law Review 121.

The action of leading or bringing: " $\dagger$ 'duction, n.". OED Online. March 2012. Oxford University Press. http://www.oed.com/view/Entry/58212? redirectedFrom=duction (accessed June 03, 2012).

6 BAH (presumably BA Hepple) ‘Sir Otto Kahn-Freund, Q.C., FBA. 1900-1979’ (1979) 8 Industrial Law Journal 193.

7 Dukes Ruth 'Otto Kahn-Freund and Collective Laissez-Faire: An Edifice without a Keystone?' (2009) 72 Modern Lan Review 220 at 224-225.

$8 \quad$ Glasser Cyril 'Radicals And Refugees: The Foundation of The Modern Law Review and English Legal Scholarship' (1987) 50 Modern Law Review 688.
} 
gentleman and of a nobleman and even of "persons of inferior rank, especially those of the learned profession"'. ? But that was not Kahn-Freund's point. It was merely the hook he used to draw his audience into his real argument: that it was impossible to be a fully formed lawyer unless the lawyer was educated in the humanities: "education is necessary in the untranslatable sense of the words ... "formation" or "Bildung" which denote the forming of the personality as well as the inculcation of knowledge..$^{10}$ For Kahn-Freund, the university educated lawyer would know law, as well as philosophy and history because a legal education comprising only rules and doctrines, dogma and detail, would never result in Bildung.

But Kahn-Freund did not cite Blackstone's dismay at the idea that lawyers would forsake a liberal or 'academical' education completely. Blackstone's Inaugural Lecture complains of:

... a practice, which, if ever it had grown to be general, must have proved of extremely pernicious consequence. I mean the custom by some so very warmly recommended, of dropping all liberal education, as of no use to students in the law ... should this infatuation prevail to any considerable degree, we must rarely expect to see a gentleman of distinction or learning at the bar. And what the consequence may be ... [that law will] fall wholly into the hands of obscure or illiterate men, is a matter of very public concern (emphasis added). ${ }^{11}$

Blackstone's prescribed curriculum drew on the theologically driven seven sciences of the Middle Ages, ${ }^{12}$ and its secular Renaissance counterpart, the litterae humaniores, in effect to advocate a Law 'Greats': 13

If therefore the student in our laws has formed both his sentiments and style, by perusal and imitation of the purest classical writers, among whom the historians and orators will best deserve his regard; if he can reason with precision, and separate argument from fallacy, by the clear simple rules of pure unsophisticated logic; if he can fix his attention, and steadily pursue truth through any [sic] the most intricate deduction, by the use of mathematical demonstrations; if he has enlarged his conceptions of nature and art, by a view of the several branches of genuine, experimental philosophy; if he has impressed on his mind the sound maxims of the law of nature, the best and most authentic foundation of human laws; if, lastly he has contemplated those maxims reduced to a practical system in the laws of imperial Rome; if he has done this or any part of it, (though all maybe easily done under as able

Kahn-Freund above note 4 at122, citing Blackstone "On the Study of Law" at his note 3-5.

10 Kahn-Freund above note 4 at 123

11 Blackstone William Commentaries on the Laws of England Book the First: Introduction. Of the Study, Nature and Extent of the Laws of England 'Section the First: On the Study of Law' $4^{\text {th }}$ edition Clarendon Press Oxford 1770 pp 31-32. I have modernised the $18^{\text {th }}$ century spellings.

12 "science, n." OED Online March 2012 Oxford University Press 24 May 2012 <http://www.oed.com/view dictionaryentry/Entry/172672> : the Trivium (Grammar, Logic, Rhetoric) and the Quadrivium (Arithmetic, Music, Geometry, Astronomy).

13 The BA in Litterae Humaniores, nicknamed Greats, is known as the most difficult course at Oxford, comprising the study of Greek and Roman classical literature, philosophy, and ancient history among other subjects. Modern Greats or PPE comprises Politics, Philosophy and Economics. 
instructors as ever graced any seats of learning) a student thus qualified may enter upon the study of the law with incredible advantage and reputation. ${ }^{14}$

This was not quite what eventuated. It took another 100 years before a BA in Law was established at Oxford. ${ }^{15}$ Yet '... memories of Blackstone led to claims that the "Laws of England" were, in their very nature, the course best suited "for a modern liberal education in England"“ (emphasis added). ${ }^{16}$ But unlike Blackstone's prescription, there was little or no liberal education of the kind he advocated. Not only did law at Oxford until the end of the 1950s acquire a reputation as being a course for dullards, ${ }^{17}$ as late as the present the view persists in England that it is better to obtain a broader education than a law degree, ${ }^{18}$ especially for those who want a career at the Bar. In short, the view is taken that anyone can learn law at one or other one-year post-non-law-degree course, especially if you had, like HLA Hart, already studied the most difficult course of all, Greats. They 'could get law up in the long vacation'.19 Jonathan Sumption, who was appointed to the UK Supreme Court in 2012, an Oxford history don before becoming a barrister, was reported as once saying 'that studying law at university "narrows the mind and blunts curiosity".$^{20} \mathrm{He}$, of course, did not study law at university.

All this begs the question: if those practising law at the London Bar, in the senior ranks of the legal profession, in the 'home' of the common law rejected the study of law, favouring the humanities as their preferred course of study instead, what went wrong? Was the practice of law-law reported in the cases, law contained in advices-so divorced from the original disciplinary foundations of its members that it counted for nothing? Once the classicists, historians and philosophers became lawyers, the literal law became present and future, and the ghostly recollections of humanities past rendered nugatory. Memories of Blackstone past indeed; the Blackstone of the recent past and present was verballed, the book and authority read to conform to a cramped and imagined legality bereft of humanity in all of its forms. It could not have just been the university graduates of law schools and departments-Oxbridge, London

14 Blackstone above note 11 at 33.

15 A School of Law and Modern History was established in 1850. If students wanted to study law, they first had to take Greats and then complete Law and Modern History. This looked very like Blackstone's formula, but following a minor change, the system changed in 1877 to one that was concerned with law only. However, the law taught was largely unrelated to a practitioner's conception of law, with very little 'English' Law taught even up to the 1950s: Simpson Brian Reflections on the Concept of Law Oxford University Press Oxford 2011 pp 18 -19.

16 Baron Wedderburn of Charlton 'An Anniversary Preface' (1987) 50 Modern Law Review 673 at 673.

17 Brian Simpson recalls that in the 1950s he had to fight the admission 'of weak candidates' to his Oxford college on the basis that 'if they could not cope with classics, or history they could always read law': Simpson Brian 'Herbert Hart Elucidated' (2006) 104 Michigan Law Review 1437 at 1438 -1439. He notes that neither English nor Geography would take rejected Law candidates - the imputation is that these were even more lowly on the Oxford scale than law: Simpson above note 15 at 67.

18 Aldridge Alex 'Is the law degree an ass? With Britain's legal pre-eminence under threat, the value of our system of beginning legal education at 18 is being questioned' The Guardian http://www.guardian.co.uk/law/2011/oct/14/lawdegree-an-ass-education

19 Simpson above $\mathrm{n} 15$ at 65

20 Aldridge Alex 'Tuition fees are making law conversion courses less attractive' The Guardian Thursday 18 August 2011 http://www.guardian.co.uk/law/2011/aug/18/tuition-fees-law-conversion-courses 
(during the 1960s that meant Kings, the LSE and UCL) and the provincial law schools-who bled law of its humanity. It must also have been those humanists themselves, those lawyers who had received a humanistic education before embarking on a truncated legal education, to become inured to a law devoid of the humanities. Law thus tell tales about itself. We live in the world of the imagination in law, as Richard Mohr's illuminating account of the role of the hidden, representation and tradition shows. ${ }^{21}$ We draw on imagined and fantastic images of the past (whether we want to believe it or not) as Peter Goodrich reminds us:

The projective distance of the origin signals a different reality, another order of causes, and with it a preponderance of figures of fantasy: chronographia or the counterfeit of time, topographia or description of imaginary places, and finally noema, the figure of close conceit, of an esoteric knowledge, a private or initiate reasoning. ${ }^{22}$

Kahn-Freund knew this. Drawing on Blackstone as authority — and sanctity — for his own entirely foreign position, he asserted that the universitas literarum, the 'all-round humanistic university education' born in Prussia in 1810, ${ }^{23}$ should form the model for a legal education. Note not just that law be taught in a university, but it needed to be taught with the humanities-and the social sciences:

I do not believe that any student of law can understand his subject nor do I believe that legal education deserves its name unless law is taught in the frame of a universitas literarum or scientarum, that is in conjunction with other disciplines. ${ }^{24}$ As the often quoted Blackstone said: "Sciences are of a sociable disposition, and flourish best in the neighbourhood of each other; nor is there any branch of learning but may be helped and improved by assistances drawn from other arts." Blackstone thought in terms of history and of philosophy ... we add all the social sciences to his catalogue of good neighbours. ${ }^{25}$

This argument set about asserting the need for the dual, broad education that had been his own-not one or the other, but an integration of the humanities (now broadly conceived to

21 Mohr Richard 'Signature and Illusion: Lessons from the Baroque for 'Truth' in Law, Arts and Humanities'(2012) 36 Australian Feminist Law Journal 45 at 47-48

22 Goodrich Peter 'The New Casuistry' (2007) 33Critical Inquiry 673 at 680. See also Hobsbawm Eric and Terence Ranger (eds) The Invention of Tradition Cambridge University Press Cambridge a 1993

23 With the establishment of the University of Berlin (renamed the Humboldt-Universität zu Berlin in 1949 in recognition of both Wilhelm von Humboldt (who founded the institution) and his scientist brother Alexander), the "Universitas litterarum" would achieve a unity of teaching and research and provide students with an all-round humanist education: Short History: The Vision of Wilhelm von Humboldt http://www.hu-berlin.de/ueberblick-en/history/huben_html.

24 The website of Humboldt-Universität describes the style of institution that Humboldt and the other founders of this 'reform' university wanted to create. They 'envisage[d] the integration of the natural, social sciences and humanities', The first faculties were the 'classical faculties of Law, Medicine, Philosophy and Theology': The Modern Classic of the Reform University http://www.hu-berlin.de/ueberblick-en/history.. The original principles are maintained now, and the university website notes: 'Humboldt-Universität embodies the ideal of a universitas litterarum in the heart of Berlin. Its subject diversity spans from the humanities to the social, cultural, natural, human and medical sciences': About the University http://www.hu-berlin.de/ueberblick-en/humboldt-universitaet-zu-berlin-en

25 Kahn-Freund above note 4 at 128 (footnote omitted). 
include the social sciences) into law. And not just for the sake of some vague notion of 'policy' so much beloved by social science inclined lawyers, including those at the LSE. But in drawing on the past, those imaginary places, could only work if he took his audience along with him. Ever courteous, ${ }^{26}$ Kahn-Freund helpfully decoded these unknown concepts as he went alonguniversitas literarum (or litterarum) one minute, science the next. While the universitas litterarum was largely unknown outside Germany, Kahn-Freund was also unsure if this English audience could correctly decode Blackstone's meaning when he used the word 'science'. It was only in the 19th century that the now dominant ordinary usage denoting the natural and physical sciences took hold. ${ }^{27}$ The modern mind would encode the natural sciences, ${ }^{28}$ especially one not trained in Latin or classical languages. ${ }^{29}$ In the marvellous 1980 s BBC television series' Yes Minister and Yes Prime Minister, written by Antony Jay and Jonathan Lynn, the LSE is constantly ridiculed by Oxbridge educated civil servants. Minister/Prime Minister Hacker, a man in his late 30s/early 40sfictionally - studied at the LSE seemingly in the 1960s. ${ }^{30}$ The following exchange takes place between two senior civil servants in a 1982 episode. Thank goodness Sir Arnold is kind enough to translate for the less literate of us as well. ${ }^{31}$

Sir Mark Spencer: But Sir Humphrey Appleby is bound to tell Hacker he'd be crazy to take it on.

Sir Arnold Robinson: Yes. "Timeo Danaos et dona ferentes", I can hear him say. "Beware of Greeks bearing gifts", roughly translated. Though Humphrey would have put it in English for Hacker's benefit. Hacker went to the LSE, you know.

Sir Mark Spencer: So did I.

Sir Arnold Robinson: Oh, I am sorry.

There was no more stark a difference between Oxbridge institutions and those members of the University of London, particularly the still new LSE with its social and perhaps socialist tendencies. When Kahn-Freund arrived in London '... an accomplished legal sociologist ... [,] [a]t that time, the Law Department of the London School of Economics was perhaps the faculty in Britain in which that attribute [his being a legal sociologist] was most accounted an

26 'He was a generous warm-hearted man some say too generous-who found it hard to speak harshly of others': Wedderburn above $\mathrm{n} 2$ at 610 .

27 'science' above note 12.

28 Having not been able to learn any classical languages at school in the first part of the 1970s-they weren't offered and I wouldn't have accepted in any case - I would have been hopelessly wrong but for the motto of my alma mater -Scientia ac Labore. I did 'Arts' at the University of Queensland in the late 1970s before I did 'Law' at another university many years later.

29 The LSE had a social sciences orientation. It was established in 1895 by well-known members of the Fabian Society: Beatrice and Sidney Webb, Graham Wallas and George Bernard Shaw for the betterment of society, and the degrees it awarded were principally dedicated to the social sciences. The LSE was a research institution from the outset: LSE History: http://www2.lse.ac.uk/aboutLSE/lseHistory.aspx

30 It is mildly ironic that the LSE's motto came from Virgil's Georgics, the phrase rerum cognoscere causas: to know the causes of things.

31 Yes Minister 'Bed of Nails'. 
advantage.'32 Wedderburn's sub-text was caustic_Kahn-Freund's qualifications and background would have been a disadvantage elsewhere. The LSE Law Department suited his style of lawyering, and he it. The Modern Law Review was established from its ranks in 1937. That journal was as radical in its time as it was contextual, challenging jurisprudential orthodoxies and practices. ${ }^{33}$ Its aims and purpose rancoured the legal establishment so much that Lord MacMillan, in launching it, was moved to remark:

The epithet "modern" may arouse some misgiving ... [and] there is another aspect of modernity which is distasteful, a pert assumption that tradition and authority have nothing to teach us and that if we only use a new-fangled and sufficiently portentous vocabulary we are necessarily thinking new thoughts. ${ }^{34}$

The challenge to establishment values had changed little in the 1960s at Oxford. Though Kahn-Freund styled this special lecture a valediction to the LSE ${ }^{35}$ by the time he delivered it in 1965 he had spent enough time at Oxford to realise he was in the company of colleagues dismissive of and downright hostile to the critical and the social. The tone was set by the barrister and former Vice-Chancellor: 'Stallybrass inveighed in 1948 against ... "the great dangers of the increasing development of social studies" ". ${ }^{36}$ HLA Hart, who arrived at Oxford four years later, shared these views. He was 'terribly mistrustful of sociology in general'. ${ }^{37}$ Simpson notes that law at Oxford of the time was 'a world of eccentric dons and intellectual Cyclopses-isolated and closed to broad, interdisciplinary exchange ... [and] Hart did not escape from the limitations of his intellectual world'. ${ }^{38}$ These limitations were not confined to the social sciences. Hart was disdainful of modes of inquiry into law beyond analytical philosophy; he was dismissive of those involved in or who drew on continental philosophy. His dispute with Lon Fuller is legendary, but Hart's distaste for Fuller's approach—conventionally seen as a dispute between a positivist and a natural lawyer - is in part based on Fuller's allegiance to Germanic philosophical traditions (and it seems, his questionable philosophical credentials): 'Fuller was worth talking to. He was very much on the defensive. He was a self-taught philosopher, Germanic rather than Hegelian; and I was not'. ${ }^{39}$

Hart's new colleague not only worked with the dangerous social sciences, but he was trained in the German philosophical tradition as well. It is hard to imagine that these attitudes did

32 Wedderburn above note 2 at 610.

33 Wedderburn above note 16 at 673 . Though he did not join the editorial committee for another eight years), Kahn-Freund is counted as one of the founders of the journal.

34 Lord Macmillan 'Prefatory Note' (1937) 1 Modern Law Review 3 at 3.

35 Kahn-Freund above note 4 at 121.

36 Wedderburn above note 16 at 673 . Simpson notes that Stallybrass was a barrister who had never taken a law degree. He was a law tutor, who was later appointed Principal of Brasenose College in 1936, and Vice-Chancellor of Oxford in 1947. He died in 1948. Simpson Brian Reflections on the Concept of Law Oxford University Press Oxford 2011 p 65.

37 Sugarman David 'Hart Interviewed: HLA Hart in Conversation with David Sugarman' (2005) 32 Journal of Law and Society 267 at 289.

38 About the Book: A. W. Brian Simpson Reflections on The Concept of Law' Oxford University Press Website: http://ukcatalogue.oup.com/product/9780199693320.do

39 As above at 279. 
not rankle the genial German Jew who now called Oxford home. That Kahn-Freund summoned Blackstone - man and ghost - was strategic and rehabilitatory, calling to one of Oxford's own, the venerated one. His lecture was thus seemingly directed beyond the walls of the LSE as well as within. He was not advocating a return to a mode of encounter with the humanities as an empty return to the classics, just as he was not advocating an empty deployment of the social sciences, but one adapted to here and the now, and to all lawyers, not just those taught within the confines of the university.

\subsection{BRIGHT YOUNG THINGS}

The unifying thread of his entire career was a critical analysis of law in society, unsurpassed in grasp or scope, combined with personal conviction. He was able to express his penetrating vision with a vividness of language unusual among lawyers and to enliven his lectures and writings from the worlds of history, politics and literature. ${ }^{40}$

Kahn-Freund's lecture dazzles, with its nods to the temperament and prejudices of his adopted country; a scholarly colossus revealing a deep literary, historical, sociological, classical, theological knowledge, drawing on the law and methods of his adopted country and the country of his birth, his German educational heritage revealed in its interweavings and allusions, its tropes and images. He demonstrates to Oxford's classicists that he knows Latin and Greek, that his knowledge of Roman law is exemplary. From this base he can answer the claims that continental philosophy and the social sciences are dangerous. The lecture has its prosaic moments, too. It is heavily weighted towards the social, and the scientific. Law-conventional law-was in a new mode too, but one which spoke to itself. The New Jerusalem of Hart's co-option of Austin (not Austin's) ordinary language theory held a mirror up to law, consoling lawyers' conventionalism. Hart was the saviour of law, The Concept of Law blasting through the legal imagination.

In this climate, I draw out a passage for us to consider. I underscore that this was 1965, years before any critical scholarship grounded in the humanities would appear in the AngloAustralian common law world, Kahn-Freund mused that:

law as an academic discipline is closer to theology than to the social sciences whose subjectmatter it shares. The revolution in scientific thinking inaugurated by Francis Bacon has not extended to the law and can never fully do so. Our so-called "science" is still and will forever be based on the interpretation of sources the validity of which is assumed ... These legal "authorities" occupy in our field the place which Aristotle occupied in the philosophical thinking of the earlier Middle Ages ... It was not for him nor for his master to question the book itself. I say again: it is in the nature of law that its devotees are for ever condemned to live in a pre-Baconian world. ${ }^{41}$

BAH above note 6 at 194

41 Kahn-Freund above note 4 at 123-124. 
When we reflect on this passage, we have to remember that Kahn-Freund was known for his work in substantive areas of law, rather than as a legal theorist. ${ }^{42}$ That is not to say that he was not a legal theorist, but the point here is that he is the fully formed scholar and lawyer who can do what Jeanne Gaakeer demands of scholarship in law and the humanities - the humanities that shape and form the lawyer that is the point of the interdiscipline of law and humanities. ${ }^{43}$ This too was Otto Kahn-Freund's point-not one or the other but an interdiscipline, doing both together to illuminate law. ${ }^{44}$

But this is not the only reason why I have fallen on this passage for special attention. We see, with the acute benefit of hindsight, that his words are prescient. They seem to be of our time, our own conception of law and humanities, the interdiscipline it marks, the same questions that we ask, the same dialogue and debate that marks modes of law and humanities inquiry in the second decade of the $21^{\text {st }}$ century. That prescience is of the future from the past. Obliquely, the man who was part of the intellectual milieu of Weimer Germany, ${ }^{45}$ and friend of members of the Frankfurt School, ${ }^{46}$ has spoken the language of law and humanities present.

There is the warning about Bacon-as Rick Mohr warns, ${ }^{47}$ too-and the pretence of scientism in law-surely a barb directed towards Hart and the ghosts of the Younger Austin and Elder Austin. We see the same thing in Greta Olson's account of the development of a science of law in the early $19^{\text {th }}$ century. Jacob Grimm-he of the fairytales-was also a lawyer and philologist, a student of von Savigny at Humboldt's University of Berlin. Grimm wanted law to concentrate on its cheerfulness, and not descend into scientism-a metaphor surely for arguing against neat and comprehensive binaries. ${ }^{48}$

Kahn-Freund reminds us, as Peter Goodrich was to do after everyone else forgot about it, to conceive of law as rhetoric. ${ }^{49}$ He reminds us of the book and its authority. In displaying his

42 I wondered why his name rang a bell when I stumbled across this article. A quick perusal of Lloyd's Introduction to Jurisprudence showed me why. Lord Lloyd had summarised the key points of this article in one of the opening paragraphs of the first chapter of the thousand or more pages that make up the book. My own collection goes back to the 1985 edition, and it was there then as well. I can only guess, as I haven't been able to track down older editions, that Lord Lloyd had summarised the lecture at least from the third edition.

43 Jeanne Gaakeer 'Reverent Rites of Legal Theory: Unity -Diversity-Interdisciplinarity' (2012) 36 Australian Feminist Law Journal 19 at $39-42$

44 Kahn-Freund above note 4 at 129

45 Dukes entitled her biographical notes on Kahn-Freund as 'Kahn-Freund In The Weimar Republic': Dukes above note 7 at 223 .

Goethe's fame came about in Weimer, and for this reason, the city 'was chosen in 1919 as the venue for the national assembly, convened to draft a new constitution for what would become known as Germany's Weimar Republic': 'Johann Wolfgang von Goethe' http://en.wikipedia.org/wiki/Johann_Wolfgang_von_Goethe as at 17 May 2012.

46 Weiner Richard 'Retrieving civil society in a postmodern epoch' (1991) 28, The Social Science Journal 307; Wiggershaus Rolf (trans Michael Robertson) The Frankfurt School: Its History, Theories, and Political Significance MIT Massachusetts 1995 p 230; Bernstein Jay (ed) The Frankfurt School: Critical Assessments Routledge London 1994 p 265

47 Richard Mohr above note 23

48 Olson Greta 'Law is not Turgid and Literature not Soft and Fleshy: Gendering and Heteronormativity in Law and Literature Scholarship'(2012) 36 Australian Feminist Law Journal 65 at 68-70

49 Pether Penelope 'Measured Judgments: Histories, Pedagogies, and the Possibility of Equity' (2002) 14 Law and Literature 489 at 498-498, citing Goodrich Peter 'Rhetoric and Somatics: Training the Body to do the Work of Law in (2001) 5 Law Text Culture 241 and Goodrich Peter 'Law' in Sloane Thomas Encyclopedia of Rhetoric Oxford University Press Oxford 2001. 
erudition, and more than an abundance of charm, Otto Kahn-Freund gives us rich pickings to remind us that there were later humanists who were also lawyers. ${ }^{50}$ Seeping into its interstices, and much before the revival of law told through the humanities of the last 30 years-whether it be law and literature or law and popular culture or law and one of the other myriad streams of the humanities that are considered in this special issue of law and humanities futures-this scholar, little known to legal theory but a giant in the other areas of the law, must have dazzled this mid 1960s audience with the wit and wisdom borne of his own deep humanity and of his deeply imbricated formation-or Bildung - that gave him more than mere knowledge of the disciplines and discourses on which he drew. If they had understood it, of course, if they could see beyond the dazzling glare of Hart's new jurisprudence, for we are still talking about law in the 1960s.

One small thing must be dealt with before I move on. I have not yet stopped to parse the 'theology' of which Kahn-Freund speaks. He references here, of course, both the literal theological origins of law-the original queen of the sciences - and its devotion to the book, but also harks to Kantorowicz, ${ }^{51}$ and to Schmitt. But it is in connection with Schmitt that a further image is thrown out into another of Kahn-Freund's articles, this one written near the end of World War Two. In 1944, Kahn-Freund cited the latter with steel in his heart, and a point to be made:

In a sense which it is not easy to grasp for an Englishman, the Nazi jurist Carl Schmitt was right when he said that the power to declare a state of siege was the final test of sovereignty'. ${ }^{2}$

I wish to pause for a moment to underline this short, stinging sentence, the cold fury that it contained. His obituarist said that '... totalitarianism was the one thing for which he would express his utter detestation, ${ }^{53}$ but the phrase 'the Nazi jurist Carl Schmitt' was the key object of the sentence. No mere political theology this. These two men had lived and breathed the same air and walked the same streets. It would be naïve to think that this was not personal. Schmitt (18881985) joined the Nazi Party on 1 May 1933, a month after Kahn-Freund was removed from his judicial post and just before he had to flee, fearing for his life. Schmitt, despite his later protestations, was not a pretend Nazi. In 1936, he demanded that German law be cleansed of the 'Jewish spirit' and as an academic demanded that all publications by Jewish scholars be marked with a small symbol. ${ }^{54}$ Kahn-Freund the Jewish judge and scholar was firmly in his sights. That we cite this man-even to denounce him-is to rinse away his complicity in genocide, to

Goodrich above note 1.

51 Kantorowicz, also Jewish but right-wing, held the chair of medieval and modern history at the University of Frankfurt until he, too, was forced to leave in 1934 : Giesey Ralph E 'Ernst H. Kantorowicz: Scholarly Triumphs and Academic Travails in Weimar Germany and the United States' (1985) 30 Leo Baeck Institute Yearbook 191; Monod Paul 'Reading the Two Bodies of Ernst Kantorowicz' (2005) 50 Leo Baeck Institute Yearbook 105.

52 Kahn-Freund Otto 'The Weimar Constitution' (1944) 15 The Political Quarterly 229 at 233.

53 Wedderburn above note 7 at 610 .

54 'Carl Schmitt' Wikipedia http://en.wikipedia.org/wiki/Carl_Schmitt 
humanise inhumanity. ${ }^{55}$ Kahn-Freund the scholar used Schmitt the Nazi to underscore his rage. This was visceral, and we must read this sentence against the backdrop of the horrors of Auschwitz and Dachau and all the others that were about to be unveiled to the world after victory in Europe in 1944.

\section{'Humanities. Humaniores. Humanitatis.'}

What Schmitt shows us is that it is possible to be uncivil and inhumane and to have knowledge of and an understanding of the humanities - as a scholarly exercise. Yet it is a distortion of the true character of the humanities as expressed through Bildung-that very German concept to which I will come shortly. Kahn-Freund himself was much too civil and civilised to say more about Schmitt than he did. But he said enough for us to understand.

\section{'Humanity. Humanitas. Humanität.'}

That the genocidal impulse was not washed away after the horrors of Nazism is the great tragedy of the latter part of the $20^{\text {th }}$ century. That Rwanda and Yugoslavia could also happen-places that resonate with new horrors-is incomprehensible. The impotency of law to stamp out inhumanity is a conundrum, despite the plethora of rights designed to protect the human. The denial of the humanity of the people harmed, the women raped, the people killed in the genocidal evils has led to a revised conception of law and humanities, as a humanity plural and multiple. We should remember that 'the humanities' were also known by the singular bumanity. ${ }^{56}$ Law and humanities past and present may be limited to the humanities in its sense of the litterae bumaniores, the humanities of the scholarly. Law and humanities present and future reaches beyond the civil and civilising forces that the scholarly humanities were thought to instil-to speak to humanity, the humane and the human. The gap between the two forces us to reconceive the idea of the very characteristic of what we mean by the humanities, to properly conceive of a law and humanities futures. A new mode of encounter is drawn upon in order to frame this new humanity-the photograph, the text, the physical. The immediacy of these media humanises, but also requires that we think about what they tell us, how we need to respond.

For as Tim Peters reminds us, savagery is internal to civilisation and that it is perhaps also internal to humans. This savagery is represented in Star $W$ ars 'in the very internal struggle that is presented between the Good and the Dark Side of 'the Force'. ${ }^{57}$ But though modern allegory and mythologies can convince, it is only when we see ourselves in the frame as it were that the effects of inhumanity are brought home. Honni van Rijswijk shows what happens through a theatrical mode of encounter, when the atrocities of the war in Yugoslavia are transported theatrically to

55 In the context of Agamben see Fraser David 'Dead Man Walking: Law and Ethics After Giorgio Agamben's Auschwitz' (1999) 12 International Journal for the Semiotics of Law 397 at 412-413.

56 humanity, n. OED Online. March 2012 . <http://www.oed.com/view/Entry/89280>; accessed 01 June 2012

57 Peters Timothy D '"The Force" as Law: Mythology, Ideology and Order in George Lucas's Star Wars' (2012) 36 Australian Feminist Law Journal 125 at 138 
Leeds, ${ }^{58}$ to perhaps make it easier for 'an Englishman to grasp' (as Kahn-Freund put it) the cadence of the inhuman and the inhumane. The realities of an experience show us that international criminal and human rights law dealing with sexual violence in conflict zones becomes fiction. And Karen Crawley and Olivera Simic show us through a disturbing aesthetic, that harms to the bumanity of raped Rwandan women and children born of those rapes in warare perpetuated over and over through their representation by a white male photographer who tells their story, contrary to the interests of their safety. As they point out, the 'photographs alone convey very little of the trauma, violence and degradation of the accompanying stories-a viewer could easily pass over them'. ${ }^{59}$ We become safe again behind the aesthetic, allowing us to rinse our hands of any involvement or complicity in the forces that allow genocide to happen.

\subsection{THE WHOLE MAN}

For Otto was a whole man. To his qualities as a scholar, he added a profound humanity, a commitment to liberal values and a belief in progress in the finest tradition of social democracy. To his intellectual life he added a passionate love of music, literature and the countryside. ${ }^{60}$

Those who knew Otto Kahn-Freund were aware that his own deeply ingrained identification with the civilising character of the humanities could only have come about because of his own immersion in Bildung at the gymnasiums and universities of Germany. These ideals were betrayed by scholars like Schmitt whose slide into Nazism represented a distortion of its broad aims. But Bildung designed to inculcate through the style of education created at Humboldt's University of Berlin, also drew heavily on the creation of a nationalising sentiment and aspiration. ${ }^{61}$ Yet despite the foreign word, Bildung was not an entirely unknown-indeed, it was familiar to anyone who had been schooled in the mode of Matthew Arnold's 19th century concept of the 'whole man'. Blackstone too was concerned that as well as knowledge, the lawyer needed to have a formed personality:

And therefore to the qualities of the head, which I have just enumerated, I cannot but add those of the heart; affectionate loyalty to the king, a zeal for liberty and the constitution, a sense of real honour, and well grounded principles of religion; as necessary to form a truly valuable English lawyer ... that these endowments of loyalty and public spirit, of honour and

58 van Rijswijk Honni 'Towards A Feminist Aesthetic of Justice: Sarah Kane's Blasted As Theorisation Of The Representation Of Sexual Violence In International Law'(2012) 36 Australian Feminist Law Journal 107 at 115

59 Crawley Karen and Olivera Simic 'Unintended Consequences: Representations of Rwandan Women and their Children Born From Rape'(2012) 36 Australian Feminist Law Journal 87 at 102-103

60 Wedderburn above note 2 at 612.

61 Liedman Sven-Erik 'In Search of Isis: General Education in Germany and Sweden' in Rothblatt Sheldon and Björn Wittrock (eds) The European and American University since 1800: Historical and Sociological Essays Cambridge University Press Cambridge and New York 1993 p 74. 
religion, are no where to be found in more high perfection than in the two universities of this kingdom. ${ }^{62}$

The head and heart is precisely what Bildung was about, and why Kahn-Freund could claim that Blackstone had sought formation of the lawyer through Bildung-even beyond the original 'two universities'. But we see one other side to Bildung, beyond the idea of Queen and Country. And that was a sense of national and cultural identity inculcated through the German education system. ${ }^{63}$ It remained with him long after he escaped from Germany. Asked in 1979 (the year of his death) about his decision to remain in England after the war, he replied:

Did I consider going back after the War? I'll answer with Goethe: In demselben Flusse/Schwimmst du nicht zum zweitenmal ${ }^{64} \ldots$ The past is too strong, the emotional influence of the past is too strong. ${ }^{65}$

He remained true to his affections for a true spirit of Bildung. Kahn-Freund the nature lover quoted Germany's national poet, scientist and lawyer-Goethe-in German. Like Kahn-Freund, Goethe (1749-1832) was from Frankfurt. ${ }^{66}$ The quote is taken from Goethe's 1803 poem 'Dauer im Wechsel' ('Permanence in Change'):

Gleich mit jedem Regengusse

Ändert sich dein holdes Tal

Ach, und in demselben Flusse

Schwimmst du nicht zum zweitenmal
Half a rainy day, and there's your Pleasant valley not the same.

None could swim that very river

Twice, so quick the changes came ${ }^{67}$

As well as the implications rendered by the poem's title, I have included all the words of the second part of the second verse, which preceded the quoted, as they add another level of

62 Blackstone above note 11 at $\mathrm{p} 34$.

63 Wittrock Björn 'The Modern University: The Three Transformation' in Rothblatt and Wittrock (eds) above n 61 p 303 at 321. Humboldt thought that the progress of culture could only come he said from the self-cultivation of individuals: Mosse George German Jews Beyond Judaism Hebrew Union College Michigan Press 1985 p 8.

Compare Sarat, Anderson and Frank, who draw on Lyotard to speak of a visceral distrust this Humboldtian model of the humanities evokes. They assert that the German Idealist philosophy that underpinned the creation of the University of Berlin led in a direct line to Nazism: Sarat Austin, Matthew Anderson and Cathrine O Frank 'Introduction: On the Origins and Prospects of the Humanistic Study of Law' in Sarat Austin, Matthew Anderson and Cathrine O Frank (eds) Law and the Humanities: An Introduction Cambridge University Press Cambridge and New York 2010 p 1 at 14-16 at notes 54-55.

64 Kahn-Freund received his secondary schooling at the Goethe-Gymnasium in Frankfurt http://en.wikipedia.org/ wiki/Otto_Kahn-Freund

65 Cited in Dukes as above note 3.

66 Goethe -like Kahn-Freund-was born in Frankfurt and eventually became a lawyer but only lasted a few months, as he 'wanted to make the jurisdiction progressively more humane'. 'Johann Wolfgang von Goethe' http://en.wikipedia.org/wiki/Johann_Wolfgang_von_Goethe as at 17 May 2012.

67 Nim John Frederick (trans) in Browning Robert M (ed) Goethe, Hölderin, Neitssche, and Others: German Poetry from 1750 to 1900 Continuum Publishing New York 1984 at p 71. 
poignancy and an additional resonance for German speakers-the pleasant life eradicated is symbolic of the literal change to the natural events Goethe was depicting. ${ }^{68}$

For German Jews had created their own association with Bildung: unlike the rest of Germany, Jews reached out to it in order to integrate themselves into German society. ${ }^{69}$ The tragedy was that this rendered them, yet again, different from the rest of their society. Mosse finds a fairly clear reason for these associations: Jewish emancipation and the development of Bildung occurred at the same time in the early $19^{\text {th }}$ century, ${ }^{70}$ and Bildung's educational prescriptions and identification with the nation would function as a tool to overcome inequality. ${ }^{71}$ This concept of Bildung grew on the notion of a shared humanity which was drawn from Humboldt, Goethe and Schiller. ${ }^{72}$ Mosse identifies that it was this spirit that found its way into, and continued through the Frankfurt School. ${ }^{73}$ The resonances with Kahn-Freund echo, loudly. ${ }^{74}$

Frankfurt, the place, has come up again and again in this introduction-from KahnFreund to Goethe via Kantorowicz and back. It is not accidental. Jews were granted equal rights in Frankfurt in 1864 (followed by the rest of what was to become Germany over the next five to eight years), but there were a couple of areas where they were not quite equal. Despite their adherence to Bildung, they could not become professors. When the University of Frankfurt was founded in 1914, the institution was established through a foundation, ${ }^{75}$ in part to ensure that Jews could become professors. But the University, which was renamed in 1932 after Frankfurt's most famous citizen as the Johann Wolfgang Goethe-Universität, does not acknowledge the influence of the Jewish foundations and patrons who played an important role in its establishment. It obliquely describes the circumstances of its foundation in 1914 as a unique "citizens' university," financed by wealthy citizens in Frankfurt, Germany. ${ }^{76}$ It is coy about mentioning its large number of Jewish academics before 1933, instead observing that: 'Because of

68 See also, for another level of intertextualisation, the identification of the poem as an indicator of Goethe's 'romantic science' in connection with Goethe's scientific work: Fink Karl Goethe's History of Science Cambridge University Press Cambridge 1991 at $\mathrm{p} 13$.

69 Mosse above note 63 at $\mathrm{p} 8$.

70 Mosse above note 63 at $\mathrm{p} 3$.

71 Mosse above note 63 at $\mathrm{p} 4$.

72 Mosse above note 63 at $\mathrm{p} 7$

73 Mosse above note 63 at $\mathrm{p} 7$.

74 The account of Bildung that Mosse depicts was deeply personal. Mosse also fled Germany in 1933 as a schoolboy, and after studying history at Cambridge, he eventually moved to the United States lived for the rest of his life. The Berlin Mosse-Lectures at the Humboldt-Universität zu Berlin—the university Humboldt established in 1801 -were inaugurated in 1997 by George Mosse's own lecture on "The Liberal Heritage and the National-Socialist Public". The Lectures, with the motto of 'culture and science as a public commitment' memorialise the German-Jewish heritage of the Mosse Family and the publishing house Rudolf Mosse. They are dedicated to imparting knowledge and learning in the areas of history, art history, politics, economy, art and literature. Special attention is devoted to the past and present of Jewish life and thought in Germany and Israel. http://www.mosse-lectures.de/web/index.php/en/content/aboutUs.html

75 Fritz Bauer Institut-Frankfurt am Main: Jüdisches Museum, Permanent exbibitions: Jews in Frankfurt 1800-1950: Emancipation and Exclusion: http://juedischesmuseum.de/139.html?\&L=1 and Jüdisches Museum, Permanent exbibitions: Jews in Frankfurt 1800-1950: Problems of Integration http://juedischesmuseum.de/141.html?\&L=1. I visited this museum in April 2012. I did not notice if Otto Kahn-Freund was included in the photo board of scholars and other notable individuals from Frankfurt who had to flee or were murdered during the Nazi regime.

76 Goethe-Universität Frankfurt-am-Main About the University-History: http://www.uni-frankfurt.de/english/ about/guhistory/index.html 
racial and political tensions during the Nazi era, close to one-third of the university's academic staff were dismissed during this period-more than at any other German university. ${ }^{17}$ This scant account requires a knowledge of ghosts past in order to be able to read and decode what these words do not-perhaps cannot-say. My own contribution to this collection shows what happens when the ability to decode these ghosts - the building blocks that constitute the shared and collective histories and memories that are integral to humanity and the humanities-are lost. Ditto, or is it Dido, to that thought. ${ }^{78}$ You will have to continue reading to the end, or flip ahead, to decode this little riddle, and the ghosts that reside in its interstices. In the end, it is Bildung that lights a path for law through the intersections and interdisciplines that constitute and shape the humanities in their broadest conception, of the human, of the civil, and the civilising-those concepts and ideas that we can see in and of the past and present-and to reveal what might be missing from law and humanities futures.

77 As above.

78 Leiboff Marett "'Ditto": Law, Pop Culture and Humanities and the Impact of Intergenerational Interpretative Dissonance'(2012) 36 Australian Feminist Law Journal 145 
